\title{
Labyrinths in Manuscripts
}

The following labyrinths in medieval manuscripts are not included in either Kern's or Batschelet-Massini's catalogues.

1. Oxford MS. Bodley Auct. F. 6. 4 (S.C. 2150 ), consisting of an early thirteenth-century manuscript of Boethius's Consolation of Philosophy and a fourteenth-century manuscript of Nicholas Trevet's commentary on Boethius. Circular labyrinths, each in a different hand, appear on fols. 61 av and $61 \mathrm{bv}$, at the end of the Consolation and before the commentary, which seems to have been added later. The labyrinths seem to date from the thirteenth century.

A. A maze with thirteen circuits and a center medallion labeled domus dedali. Latin verses on the signs of the zodiac precede the maze. See plate 22.

B. A clumsily drawn maze with nine circuits and a center medallion labeled domus dedali, followed by a hymn in a late thirteenth-century hand whose text reads, "In terram Christus expuit / Saliuam terre miscuit / Et serui formam induit / Dei sapientia. // Illa mundans hec mundata / Illa creans hec creata / Unde lutum fit ex sputu / Sed non sputum fit ex luto / Assignant misteria. // Christus tamen sic providet / Quod non statim cecus vidit / Numquam videt cecus natus / Nisi prius baptizatus / In aquas misterii." A rough translation: "Christ spat on the earth / And mixed his saliva with earth / And clothed the features of the [his] servant / With [by] the Wisdom of God. // That purifying, this purified / That creating, this created, / Whence mud is made from spit / But spit is not made from mud. / They call such things mysteries [miracles?]. // Christ however thus foresees / What the blind man did not see at once. / The man born blind will never see / Unless he is first baptized / In the waters of the sacrament." 
2. Florence MS. Bibl. Laur. Plut. 78.16, a fourteenth-century copy of Boethius's Consolation of Philosophy. At the end (fol. $5^{8 \mathrm{r})}$ appears a circular maze with eleven circuits and a central medallion in which a man and a woman grip the hilt of a sword. See plate 23 .

3. Paris BN. lat. 1745, containing miscellaneous MSS. of the ninth and eleventh centuries, including St. Ambrose, De fide; St. Augustine, De haeresibus; Agobard, De correctione antiphonarii; Heribertus, De haereticis; excerpts from the Old Testament; a notice of an act of Eudes, abbot of Saint-Germain, Auxerre.

A. Fol. 3ov, after Agobard's text and before Heribertus's, illustrates a labyrinth, possibly in connection with Agobard's reference to the labyrinth, mentioned in Chapter 7. See plate 5 .

B. Fol. 4or, a labyrinth after the Act of Eudes and preceding a table of contents.

Both labyrinths contain eleven circuits and a center medallion.

4. Dijon MS. Bibliothèque communale $562,125^{0-1275}$; Histoire ancienne jusqu'à César from Acre, probably based on French originals. Fol. $115^{\mathrm{r}}$ shows a spherical building with countless doors and windows, before which stands the Minotaur. One of three illuminations of the story of the Aeneid. The legend reads, "Coment cil dathenes estoient sugiet a cil de crete." See Hugo Buchthal, Miniature Painting in the Latin Kingdom of Jerusalem, pl. 113 b. See my plate 18 .

5. Paris, MS. BN fr. 9682, ca. 1300; Histoire ancienne jusqu'à César. Fol. $14^{2} \mathrm{r}$ shows the labyrinth as a three-dimensional building and the Minotaur, as above. See Buchthal, plate $151 \mathrm{c}$.

6. Paris, MS. BN fr. 20125 , thirteenth century; Histoire universelle (Histoire ancienne jusqu'à César), French provenance. Fol. $158 \mathrm{r}$ shows a quadripartite diagram, apparently with eight circuits and no central medallion, as if projected onto a sphere; the paths seem to wrap around the sphere, passing beyond our line of vision. See my plate 19 . 